\title{
30
}

Nassim W. Balestrini et al.

ies," ed. Nicole Poppenhagen and Jens Temmen, special issue, Atlantic Studies: Global Currents 15, no. 2 (2018): 218-37, https://doi.org/10.1080/14788810.2017.1384612; Nicole Popphenhagen and Jens Temmen, "Across Currents: Connections between Atlantic and (Trans)Pacific Studies," in "Across Currents: Connections between Atlantic and (Trans)Pacific Studies," ed. Nicole Poppenhagen and Jens Temmen, special issue, Atlantic Studies: Global Currents 15, no. 2 (2018): 149-59, https://doi.org/10.1080/14788810. 2017.1394131. Also see the May 2018 conference on "Transoceanic American Studies" organized by Juliane Braun and Benjamin Fagan at the German Historical Institute in Washington, DC.

17 Lowe, Four Continents, 58.

18 Alfred Hornung, "Out of Life: Routes, Refuge, Rescue," in “Excavating Lives," ed. Amy-Katerini Prodromou and Nicoletta Demetriou, special issue, a/b: Auto/Biography Studies 32, no. 3 (2017): 6o5, https://doi.org/10.1080/08989575.2017.1339999.

19 Jenny Sharpe, "The Archive and Affective Memory in M. Nourbese Philip's Zong!" Interventions 16, no. 4(2014):475, https://doi.org/10.1080/1369801X.2013.816079.

20 Ibid., 480.

21 McKittrick, "Yours in the Intellectual Struggle," 7.

\section{Outlook on Life Writing and American Studies}

Silvia Schultermandl, University of Graz, and Nassim W. Balestrini, University of Graz DOI: 10.47060/jaaas.vii.106

Having discussed five distinct areas of inquiry within life writing studies, we are acutely aware of the various interconnected themes. By way of a conclusion, we would like to sketch three particular aspects which merit extensive attention. First, the fact that all of the contributions highlight the constructedness of life writing can be seen as a call for enhancing our understanding of the mechanisms of self-representation and their implications for the represented autobiographical self and for the multi-genre phenomenon of life writing. The field of life writing studies has been instrumental in uncovering multiple phenotypes linked to medium-specific possibilities and to the contexts in which such content is generated, disseminated, and received. Thus, we will need to grapple further with researching competing and differing media selves, including the roles of curators and adapting generic forms like the scrapbook and the self-help manual as well as the economic backdrop and impact of production and distribution.

Second, our contributions illustrate the ongoing discussion about the mediality of autobiographical self-representation. What are the upsides and downsides of broadening the terms "text" and "discourse" to non-verbal media in life writing studies? Does it suffice to regard such self-depictions as "life narratives," or does this water down the particular capacities of verbal semantics? As our contempla- 


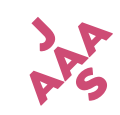

Forum: Life Writing and American Studies

tions suggest, inter- and transmedial approaches facilitate research on meaning construction and on understanding genre developments and changes.

Third, the expansive vista of transoceanic American studies, which has problematized the concerns of (hitherto mostly transatlantic and hemispheric) transnational American studies, further develops recent research on land-based as opposed to island-based or marine life narratives. The fact that island and slave ship populations have not been prominent in autobiographical research confirms once again the Western, European, and Euro-American impact on prevailing and general-readership understandings of life writing. Not only the subaltern as a subject of life narrative will be central here but also the telling of supposedly failed lives and of lives lived according to non-Western notions of temporality. Curiously enough, this discussion throws a fascinating light on some of the concerns of hip-hop life writing and its problematic relation to narratives caught between a star's socioeconomic rise and her or his activism on behalf of the disadvantaged.

Further work needs to be done in all of the above areas. Two aspects are most pressing: first, establishing a well-grounded methodology that harnesses the synergies between life writing studies and American studies; second, using the double perspective of these fields in order to navigate the affordances of life narratives that range from being locally, regionally, or nationally rooted to those implying a transnational, transoceanic, or even global reach. As the ever-evolving field imaginary of American studies has led to an expanding perspective regarding the mobility of people and texts, it has become all the more important to avoid sweeping, essentialist, and universalizing categorizations. An interdisciplinary outlook that acknowledges life writing scholarship in specific geographical and sociocultural contexts can support this trajectory.

\section{About the Forum Editors}

Nassim W. Balestrini is Professor of American Studies and Intermediality at the University of Graz, Austria, and Director of the Centre for Intermediality Studies in Graz (CIMIG). Her research interests include US-American literature and culture from the eighteenth century to the present, adaptation and intermediality, life writing, hip-hop culture, climate change theater, theater history as well as poet laureate traditions in the US and Canada.

Silvia Schultermandl is Associate Professor of American Studies at the University of Graz. Her areas of interest include affect theory, literary theory, critical race theory, queer theory, visual culture, and transnational feminism. She is currently developing the Palgrave Series in Kinship, Representation, and Difference and is embarking on a new project on kinship and social media.

Contact: Nassim W. Balestrini; University of Graz; Department of American Studies; nassim. balestrini@uni-graz.at. 